\title{
Extent of spike shedding and stem wilting of pepper (Piper nigrum L.) in Morogoro District, Tanzania
}

\author{
Abdul Jafari Shango ${ }^{*}$ (D), Ramadhani Omari Majubwa and Amon Petro Maerere
}

\begin{abstract}
Background: Pepper (Piper nigrum L.) is an important spice produced by small-scale farmers in Morogoro district of Tanzania for both local and export markets. Recently, farmers have reported a decline in crop productivity due to spike shedding and stem wilting of pepper plants. The study was conducted to obtain baseline information on the extent of the disorders.
\end{abstract}

Methods: An altitudinal transect survey was conducted in Morogoro district from October to November 2018. Data were collected from 216 pepper farmers through a questionnaire, focus group discussions, and field observations. Chi square tests $(a=0.05)$ were used to compare differences between gender, pepper cultivars by wards and yield, spike shedding and stem wilting by pepper cultivars and plant species used to support pepper vines. Fisher's exact test at $(a=0.05)$ was used to compare the effects of production constraints and altitude. A regression analysis was performed to explore the relationship between altitude and the incidence of spike shedding and stem wilting.

Results: The majority of interviewees (69\%) had observed spike shedding and stem wilting of pepper on their farms for $>3$ years. Spike shedding was more prominent at 300 meters above sea level (masl, 85.7\%), while stem wilting was reported by most (66.7\%) farmers at 457 masl. The most affected pepper cultivar was reported to be "Babu kati" in Mtombozi (19.2\% of respondents) and "Ismailia" in Mkuyuni and Kibogwa (28.9\% of respondents) wards, while in Kibungo ward cultivar "Babu ndogo" (85.7\% of respondents) and in Konde ward cultivar "Babu kubwa" (53.8\% of respondents) were most affected. Approximately $53 \%$ of respondents reporting the disorders used Jatropha to support the pepper vines, and $93 \%$ of the farmers reported the disorders to occur during the dry season. A greater proportion of the interviewed farmers (92.1\%) reported applying no measures to control spike shedding and stem wilting of pepper.

Conclusions: Incidence of spike shedding and stem wilting was higher at a low altitude compared to high altitude areas. The magnitude of the disorders differed among pepper cultivars regardless of support plants species used. Poor adoption of key agronomic practices and lack of any information on control measures may be contributing to the high incidence of the disorders in the study area. The study demonstrates the extent of the problem, and provides a baseline for identifying the causal agent(s) of spike shedding and stem wilting, which in turn will allow appropriate control measures to be selected.

Keywords: Pepper, Spike shedding, Stem wilting, Extent, Morogoro district

*Correspondence: abdulshango@gmail.com

Sokoine University of Agriculture, P. O. Box 3005, Chuo Kikuu, Morogoro, Tanzania

\section{Background}

Pepper (Piper nigrum L.) is a flowering plant in the family Piperaceae. It is a climbing, woody perennial species cultivated for its fruit. The fruit are dried and used as a

(c) The Author(s) 2020. This article is licensed under a Creative Commons Attribution 4.0 International License, which permits use, sharing, adaptation, distribution and reproduction in any medium or format, as long as you give appropriate credit to the original author(s) and the source, provide a link to the Creative Commons licence, and indicate if changes were made. The images or other third party material in this article are included in the article's Creative Commons licence, unless indicated otherwise in a credit line to the material. If material is not included in the article's Creative Commons licence and your intended use is not permitted by statutory regulation or exceeds the permitted use, you will need to obtain permission directly from the copyright holder. To view a copy of this licence, visit http://creativeco mmons.org/licenses/by/4.0/. The Creative Commons Public Domain Dedication waiver (http://creativecommons.org/publicdomain/ zero/1.0/) applies to the data made available in this article, unless otherwise stated in a credit line to the data. 
spice, having a peculiar pungent taste. Pepper is nicknamed "Black Gold" or "King of Spices." It is one of the world's oldest and most widely consumed spices. There are two major pepper products, black pepper and white pepper, that are traded internationally (Parthasarathy and Zachariah 2008).

Pepper is a native of the Malabar Coast in south western India (Purseglove et al. 1981). The crop is extensively cultivated in India and other tropical regions with suitable climate. On the Tanzanian mainland, pepper is produced largely in Muheza, Mkinga, and Morogoro districts. Offshore, pepper is cultivated on Unguja and Pemba islands in Zanzibar. These areas vary ecologically in temperature, humidity, and rainfall due to altitude (Maerere and Van Noort 2014). In Morogoro, the crop is grown along the eastern slopes of the Uluguru Mountains (Yamane et al. 2018), especially in the Matombo and Mkuyuni divisions of the province (Burgess et al. 2001).

Pepper requires high rainfall, humidity and sufficient temperature to grow successfully, and these conditions can be found at altitudes up to $1500 \mathrm{~m}$ above sea level (masl). Altitude affects elements of weather including temperature, rainfall, and relative humidity that have an impact on the crop (Ravindran et al. 2000). Pepper is adapted to a temperature and relative humidity in the range 23 to $32{ }^{\circ} \mathrm{C}$ and 75 to $80 \%$, respectively. It requires that the annual rainfall be up to $3000 \mathrm{~mm}$ and well-distributed throughout the year. Pepper is a day-neutral plant that thrives under shade (50\%); it does not tolerate excessive heat and dryness (Ravindran et al. 2000; Parthasarathy et al. 2007). It can be grown in a wide range of soils (from heavy clay to light sandy clays), that should be well-drained and rich in humus with a $\mathrm{pH}$ ranging from 5.5 to 6.5 (Thangaselvabal et al. 2008). The productive life of pepper is usually 12 to 15 years with the first crop being produced in the third year after planting (Purseglove et al. 1981).

Crop losses in many pepper-producing countries have been attributed to diseases, insect pests; other limitations to pepper production include low levels of inputs such as manure, fertilizers, and pesticides (Srinivasan et al. 2012). A range of plant pathogens infect pepper; pepper is also attacked by various insect pests including ants, flea beetles, leaf gall thrips and stink bugs (Daba et al. 2017). As noted above, environmental factors including temperature and rainfall are important for pepper production, and influence the yield of pepper directly (Parthasarathy et al. 2007). Hence, global climate change and inadequate water availability coupled with biotic stresses lead to low productivity (Krishnamoorthy and Parthasarathy 2009). In addition, the abiotic environmental factors influence the susceptibility of host plants to pests and/or diseases, reproduction of the pathogens and pests, their activity, and the interaction between the plants and its pathogens (Nguyen 2015). Lack of availability of plant nutrients in the soil can predispose the pepper plant to diseases (Srinivasan et al. 2012). Various diseases of pepper may cause spike shedding (when developing pepper flowers or berries are aborted from the spike), stem wilting, and yellowing of foliage, which are conditions that have been described in the literature on several occasions and are considered a common symptom afflicting pepper (Menon and Nair 1987; Geetha and Nair 1989, cited by Srinivasan et al. (2012) and Truong et al. (2005)). Stem wilting in Vietnam and India has been associated with diseases caused by several pathogens including the oomycete Phytophthora capsici and root-knot nematodes (Meloidogyne incognita), either alone or in combination (Truong et al. 2005; Ravindra et al. 2014; Thomas and Naik 2017). In other studies, Fusarium spp (including F. solani and F. oxysporum) have been reported to cause stem wilting of pepper plants cultivated in Brazil and Malaysia (Duarte et al. 1999, 2001; Shahnazi et al. 2012).

Spike shedding in pepper occurs at various stages of fruit development. It can lead to crop losses of $40 \%$ or more in India (Kandiannan et al. 1994). Spike shedding of pepper includes but is not limited to the dropping of flowers or berries and improper filling of berries on spikes, so that berries fail to develop to normal size. Stem wilting of pepper plants includes withering and drooping of stems, that become limp and dry. Prolonged droughts, heavy or irregular rains that can reduce pollination, affect crop physiology, and also lead to either intensive shedding of berries or failure of berry set (Srinivasan et al. 2012; Krishnamurthy et al. 2016).

The biocontrol bacterium (Curtobacterium luteum) applied in combination with the fungicide Metalaxyl significantly reduced nematode populations, and foot rot incidence due to Phytophthora spp, and increased growth and yield of pepper in India (Bhai et al. 2017). In Vietnam, a systemic fungicide (Potassium phosphonate) as a soil drench (applied at rates of 50-100 g a.i/ plant) significantly inhibited the colonisation of $P$. capsici on excised leaf, stem and root tissues (Truong et al. 2012). Endophytic bacteria (Bacillus megaterium) applied as a biocontrol, significantly inhibited nematodes in the soil (81.86\% inhibition), colonization of pepper plant roots (by $73.11 \%$ ) and reduced the nematode build-up rate to 0.23 . B. megaterium also promoted plant growth and enzymatic activities (chitinase and protease) related to the biocontrol of Meloidogyne sp (Tran et al. 2019). Foliar sprays with a plant growth regulator, 1-Naphthaleneacetic acid (NAA) at $50 \mathrm{ppm}$ (Kumar et al. 2002) with soil application of zinc sulphate at $2.5 \mathrm{~kg} \mathrm{ha}^{-1}$ (Hamza and Sadanandan, 2005) reduced spike shedding, and increased yield and quality of pepper. These studies 
indicate that spike shedding and stem wilting of pepper can have various biotic causes that are amenable to mitigation using available conventional and biological control agents.

Based on observations by Maerere and Van Noort (2014), a comprehensive survey is needed to assess the extent of spike shedding and stem wilting of pepper in Morogoro district, Tanzania. It is also desirable to identify the cause, but in this survey we sought to determine the extent of spike shedding and stem wilting among different pepper-growing villages located at different elevations along the Uluguru Mountains in north eastern Tanzania.

\section{Methods}

\section{Description of the study site}

The survey was conducted in eight wards of Matombo and Mkuyuni divisions in Morogoro district. The wards include Kinole, Mkuyuni, Kibogwa in Mkuyuni division and Tawa, Mtombozi, Kisemu, Kibungo Juu, and Konde in Matombo division (Fig. 1). The wards cover an altitude range between 200 and 1300 masl. Based on 30 years weather data for altitudes up to 779 masl (Meteoblue 2018), the wards experience a bimodal rainfall pattern with the short rains falling between late-October to the end of January and the long rains from February to May; a dry season is experienced between June to midOctober. The wards receive monthly precipitation ranging from 6 to $66 \mathrm{~mm}$ with a mean monthly minimum and maximum air temperature range of $17{ }^{\circ} \mathrm{C}$ to $20^{\circ} \mathrm{C}$ and $26{ }^{\circ} \mathrm{C}$ to $31^{\circ} \mathrm{C}$, respectively.

\section{Baseline survey}

An altitudinal transect survey was conducted in Morogoro district from October to November 2018 using standard survey procedures as described by Zaragoza et al. (1992). A total of sixteen villages (at least two per ward) were purposively selected based on their importance for pepper production (Table 1). Positions and altitudes of selected villages (16) were recorded with the aid of a global positioning system (GPSMAP $64 \mathrm{~s}$, Garmin Ltd, USA). The selected smallholder pepper farmers from

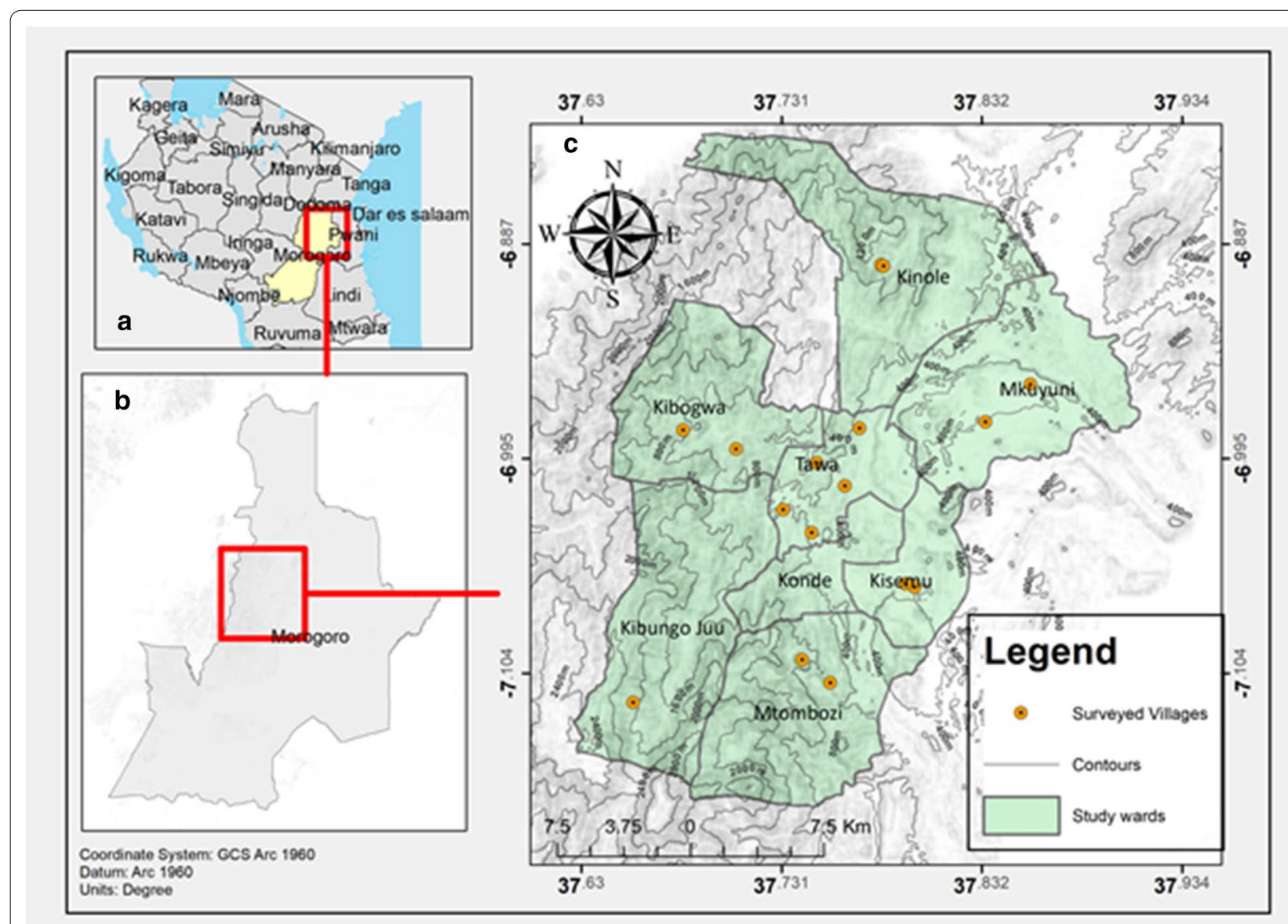

Fig. 1 a Map of Tanzania. b Morogoro District. c Wards surveyed in Morogoro district where pepper farms were surveyed for symptoms of spike shedding and stem wilting 
Table 1 Altitude and geographical location (coordinates in degrees and decimal minutes) of the villages in Morogoro district, Tanzania, where pepper farms were surveyed for symptoms of spike shedding and stem wilting

\begin{tabular}{|c|c|c|c|c|c|}
\hline Division & Ward & Village & Latitude & Longitude & Altitude \\
\hline \multirow[t]{3}{*}{ Mkuyuni } & \multirow[t]{2}{*}{ Mkuyuni } & Kibwaya & $\begin{array}{l}06^{\circ} 56.725^{\prime} \\
S\end{array}$ & $\begin{array}{l}037^{\circ} \\
\quad 48.328^{\prime} \mathrm{E}\end{array}$ & 321 \\
\hline & & Mfumbwe & $\begin{array}{l}06^{\circ} 54.032^{\prime} \\
S\end{array}$ & $\begin{array}{l}037^{\circ} \\
\quad 48.905^{\prime} \mathrm{E}\end{array}$ & 452 \\
\hline & Kinole & Tandai & $\begin{array}{l}06^{\circ} 54.521^{\prime} \\
\mathrm{S}\end{array}$ & $\begin{array}{l}037^{\circ} \\
\quad 45.450^{\prime} \mathrm{E}\end{array}$ & 457 \\
\hline \multirow[t]{13}{*}{ Matombo } & \multirow[t]{2}{*}{ Kibogwa } & Kifulu & $\begin{array}{l}06^{\circ} 54.519^{\prime} \\
\mathrm{S}\end{array}$ & $\begin{array}{l}037^{\circ} \\
\quad 45.446^{\prime} \mathrm{E}\end{array}$ & 693 \\
\hline & & Kilunga & $\begin{array}{l}06^{\circ} 57.960^{\prime} \\
S\end{array}$ & $\begin{array}{l}037^{\circ} \\
\quad 41.864^{\prime} \mathrm{E}\end{array}$ & 806 \\
\hline & \multirow[t]{5}{*}{ Tawa } & Milawilila & $\begin{array}{l}06^{\circ} 59.758^{\prime} \\
S\end{array}$ & $\begin{array}{l}037^{\circ} \\
44.738^{\prime} \mathrm{E}\end{array}$ & 377 \\
\hline & & Kisarawe & $\begin{array}{l}07^{\circ} 00.755^{\prime} \\
S\end{array}$ & $\begin{array}{l}037^{\circ} \\
\quad 44.340^{\prime} \mathrm{E}\end{array}$ & 374 \\
\hline & & Kifindike & $\begin{array}{l}07^{\circ} 02.367^{\prime} \\
S\end{array}$ & $\begin{array}{l}037^{\circ} \\
\quad 45.210^{\prime} \mathrm{E}\end{array}$ & 380 \\
\hline & & Tawa & $\begin{array}{l}07^{\circ} 00.921^{\prime} \\
S\end{array}$ & $\begin{array}{l}037^{\circ} \\
\quad 43.878^{\prime} \mathrm{E}\end{array}$ & 395 \\
\hline & & Uponda & $\begin{array}{l}07^{\circ} 01.207^{\prime} \\
S\end{array}$ & $\begin{array}{l}037^{\circ} \\
46.637^{\prime} \mathrm{E}\end{array}$ & 218 \\
\hline & \multirow[t]{2}{*}{ Kisemu } & Mtamba & $\begin{array}{l}07^{\circ} 06.088^{\prime} \\
S\end{array}$ & $\begin{array}{l}037^{\circ} \\
\quad 46.710^{\prime} \mathrm{E}\end{array}$ & 390 \\
\hline & & Nige & $\begin{array}{l}07^{\circ} 02.983^{\prime} \\
S\end{array}$ & $\begin{array}{l}037^{\circ} \\
\quad 47.243^{\prime} \mathrm{E}\end{array}$ & 300 \\
\hline & $\begin{array}{l}\text { Kibungo } \\
\text { Juu }\end{array}$ & Lukenge & $\begin{array}{l}07^{\circ} 02.812^{\prime} \\
S\end{array}$ & $\begin{array}{l}037^{\circ} \\
\quad 42.985^{\prime} \mathrm{E}\end{array}$ & 758 \\
\hline & Konde & Konde & $\begin{array}{l}07^{\circ} 03.938^{\prime} \\
S\end{array}$ & $\begin{array}{l}037^{\circ} \\
\quad 44.562^{\prime} \mathrm{E}\end{array}$ & 479 \\
\hline & \multirow[t]{2}{*}{ Mtombozi } & Lugeni & $\begin{array}{l}07^{\circ} 06.557^{\prime} \\
S\end{array}$ & $\begin{array}{l}037^{\circ} \\
\quad 44.808^{\prime} \mathrm{E}\end{array}$ & 660 \\
\hline & & Mtombozi & $\begin{array}{l}07^{\circ} 06.595^{\prime} \\
\quad S\end{array}$ & $\begin{array}{l}037^{\circ} \\
\quad 46.462^{\prime} \mathrm{E}\end{array}$ & 351 \\
\hline
\end{tabular}

mas/ meters above sea level

the villages in the eight wards comprised a sample of 216 respondents out of a total of approximately 1000 spice crops growers in the district.

\section{Data collection}

Interviews were conducted using a semi-structured questionnaire. Questionnaires were self-administered to farmers who were capable of completing them on their own, and guidance was given to farmers who needed assistance. The interviews in each village were complemented with focus group discussions. The pepper plants in the selected fields in each ward were carefully examined. The data collected from the interviewed farmers included demography, farm and crop characteristics, crop management practices, and pepper production constraints (the full questionnaire can be referred to in Additional file 1).

\section{Data analysis}

Data were descriptively analyzed to determine the distribution of respondents for each variable. The Statistical Package for Social Sciences program V16 (SPSS Inc, USA, Chicago, IL, USA) was used to calculate the descriptive statistics including frequencies and percentages for each variable of interest. In cases where a respondent selected multiple responses to a question (e.g., cultivars grown on a farm) all were included as individual data points to calculate the frequency (thus the total in some cases was not number of farms, but total number of responses for that variable). Chi square tests $(\alpha=0.05)$ were used to compare differences between pepper farmers based on gender by each age group, proportion of pepper cultivars cultivated in each ward and by yield, proportion of each pepper cultivar showing symptoms in each ward, and spike shedding and stem wilting of pepper cultivars, and the proportions of different pepper vine support species in the different wards. Fisher's exact test at $(\alpha=0.05)$ was used to compare the effects of production constraints and altitude. A regression analysis was performed to explore the relationship between altitude and the incidence of spike shedding and of stem wilting.

\section{Results}

Demographic information of interviewed farmers

Both age and gender were factors in pepper farming (Fig. 2a). Pepper farming was dominated by male farmers in the age groups $25-35$ years old (68.6\%), 35-45 years old $(63.9 \%)$ and $>55$ years old (63.3\%), but female farmers were $52.1 \%$ of farmers in the $45-55$ year old age group. The mean age was 43.9 and 45.8 years for male and female farmers, respectively. The difference in frequency of male and female pepper farmers by age group was not significant $\left(x^{2}=5.075, d f=4, p=0.28\right)$. About $15 \%$ of the interviewed farmers had been producing pepper for 4 years, $13 \%$ for 3 years and $12 \%$ for 5 years, while $13.9 \%$ of farmers had been cultivating pepper for 15 years or more (Fig. 2b). The mean period of engagement in pepper farming was 12.8 years.

\section{Respondents' farm characteristics}

The land unit devoted to pepper production ranged from 1012 to $21448 \mathrm{~m}^{2}$, although most (92.5\%) farmers had less than $8094 \mathrm{~m}^{2}$. Approximately $6 \%$ of interviewed farmers had farms of 8094 to $12141 \mathrm{~m}^{2}$, and only $1.9 \%$ had farms of more than $12141 \mathrm{~m}^{2}$. The average farm size was $3990 \mathrm{~m}^{2}$. Most (28.7\%) farmers had 6-10 pepper plants followed by $25.5 \%$ of farmers who 

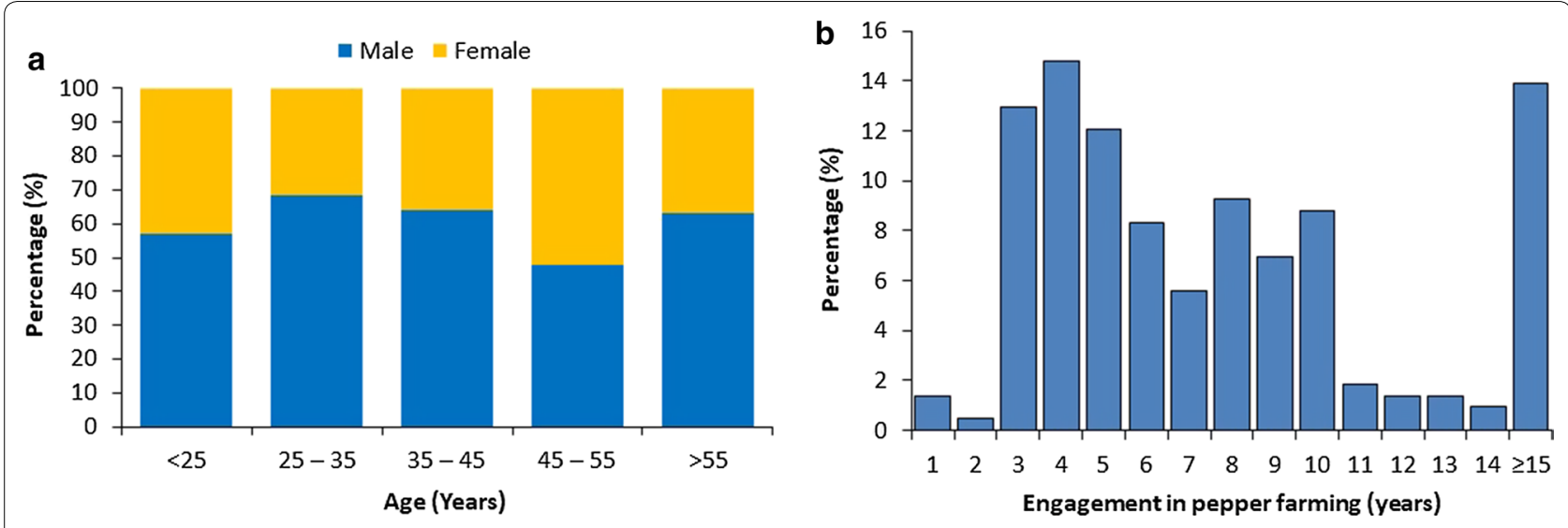

Fig. 2 Results of a survey of villages in Morogoro district, Tanzania, where pepper farms were surveyed for symptoms of spike shedding and stem wilting. a Age and sex of the respondents in the study area. $\mathbf{b}$ The duration which respondents had been engaged in pepper farming

had 11-20 pepper plants on their farms (Fig. 3a). The mean number was 25 pepper plants per farm.

The majority $(98 \%)$ of farmers reported practicing mixed cropping, while less than $2 \%$ practiced monoculture of pepper vines (Table 2). Based on field observation, pepper was grown as a secondary crop at the base of naturally occurring wood or forest trees, or cultivated fruit trees. More than two crop species were grown on the same farm, without any systematic arrangement in rows or at specific spacing. Most (84.7\%) farmers mixed pepper with fruit crops followed by those who intercropped with perennial spices (64.4\%), tuber crops (22.2\%), cereals and/or legumes
(5.1\%) and other crops (6.9\%) including vegetables, coconut, coffee and wood/forest trees (Table 2).

Seven common pepper cultural practices were identified among the farmers; (i) training pepper vines, (ii) pruning pepper vines, (iii) pruning support trees, (iv) weeding, (v) manure application, (vi) irrigation, and (vii) dry grass mulching. The interviewed farmers reported that they conducted training of pepper plants on supports and performed weeding as the most common practices on their pepper farms. Soil management practices including manure application, irrigation and drainage were not commonly practiced by farmers in the survey area, thus farmers mainly depended on seasonal rainfall for moisture for the pepper vines.
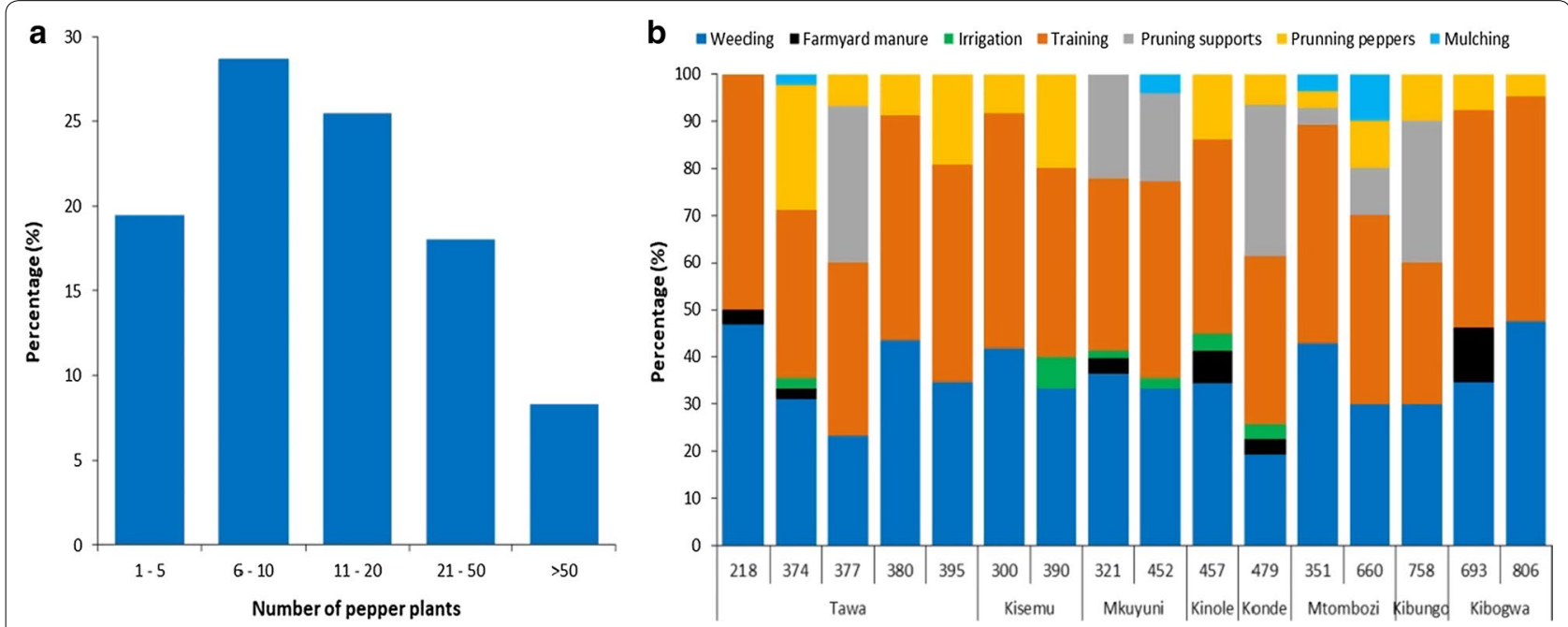

Fig. 3 Results of a survey of villages in Morogoro district, Tanzania, where pepper farms were surveyed for symptoms of spike shedding and stem wilting. a Number of pepper plants in respondents' farms. b Pepper cultural/agronomic practices in respondents' farms in the different wards and at different altitudes (meters above sea level) 
Table 2 Pepper cropping systems and in Morogoro district, Tanzania, where pepper farms were surveyed for symptoms of spike shedding and stem wilting

\begin{tabular}{|c|c|c|}
\hline Pepper cropping system & & $\begin{array}{l}\text { Frequency (percentage) } \\
\text { of respondents } n=216\end{array}$ \\
\hline Monoculture (pepper only) & & $4(1.9)^{\mathrm{a}}$ \\
\hline \multirow[t]{6}{*}{ Mixed cropping } & & $212(98.1)$ \\
\hline & Fruits & $183(84.7)$ \\
\hline & Perennial spices & $139(64.4)$ \\
\hline & Tubers & $48(22.2)$ \\
\hline & Cereals and/or legumes & $11(5.1)$ \\
\hline & Other crops & $15(6.9)$ \\
\hline
\end{tabular}

a Numbers in parenthesis indicate the percentage of respondents in the specified category; where \% totals add up to more than $100 \%$ there were multiple categories selected by responders

Table 3 Support materials used for pepper vines in Morogoro district, Tanzania, where pepper farms were surveyed for symptoms of spike shedding and stem wilting

\begin{tabular}{lc}
\hline Support material or species & $\begin{array}{l}\text { Frequency (percentage) } \\
\text { of respondents } \mathbf{n = 2 1 6}\end{array}$ \\
\hline Jatropha & $169(78.2)^{\mathrm{a}}$ \\
Jackfruit Tree & $121(56.0)$ \\
Mango Tree & $106(49.0)$ \\
Kapok Tree & $70(32.4)$ \\
Other materials & $48(22.2)$ \\
\hline
\end{tabular}

${ }^{a}$ Numbers in parenthesis indicate the percentage of respondents at specified category; where $\%$ totals add up to more than $100 \%$ there were multiple categories selected by responders

However, dry grass mulching was practiced by $10 \%$ of farmers in Mtombozi ward (660 masl), while 11.5\% of farmers in Kibogwa ward (693 masl) mostly applied farmyard manure. Only $2.2 \%$ of farmers in Tawa (374 masl), $6.7 \%$ in Kisemu (390 masl), $2.1 \%$ and $1.6 \%$ in Mkuyuni (452 masl and 321 masl, respectively), 3.2\% in Konde (479 masl), and $3.4 \%$ in Kinole (457 masl) wards irrigated their pepper plants (Fig. 3b). Although, during focus group discussions farmers emphasized a positive perception to the adoption of improved agronomic practices, they reported facing problems including lack of direction and guidance from the government through the local extension officers on technical training pertaining to spice production, including pepper.

Different supports were used for the pepper vines; $78 \%$ of farmers used Jatropha (Jatropha curcas), followed by Jackfruit (Artocarpus heterophyllus) (56\% of farmers), Mango (Mangifera indica) (49\% of farmers), Kapok (Ceiba pentandra) (32.4\% of farmers), and other materials (22.2\% of farmers) (Table 3$)$. Other materials used included coffee (Coffea arabica) bushes, silver oak (Grevillea robusta), African mahogany (Khaya anthotheca), and African plum (Vitex doniana).

\section{Cultivars and productivity of pepper grown in the study area}

Four pepper cultivars were recorded to be grown in the study area. These were; Babu kubwa (local Luguru language $=$ Komoro), Babu ndogo (Kikong'oro), Babu kati (Ya zamani), and Ismailia (Bwanashamba). The difference in proportions of preferred pepper cultivar across the different wards surveyed was significant for "Babu kubwa" $\left(\chi^{2}=20.75, d f=7, p=0.004\right)$, "Babu ndogo" $\left(\chi^{2}=25.22\right.$, $d f=7, p=0.001)$, "Babu kati" $\left(\chi^{2}=39.28, d f=7, p<0.001\right)$ and "Ismailia" ( $\left.\chi^{2}=89.35, d f=7, p<0.001\right)$. Most farmers who grow "Babu ndogo" (55.6\%) and "Babu kubwa" (45.5\%) were located in Konde and Kisemu wards, respectively. While "Babu kati" was grown by most (20.7\%) of the farmers in Mtombozi ward and "Ismailia" was grown by most (36.7\%) farmers in Kinole ward (Fig. 4a).

Yield estimates (Fig. 4b) show that most (50\%) respondents who grew cultivar "Babu ndogo" harvested $>6 \mathrm{~kg}$ plant $^{-1}$, only $(6.1 \%)$ of respondents who grew cultivar "Babu kati" harvested 1 to $2 \mathrm{~kg}$ plant $^{-1}$ and 5 to $6 \mathrm{~kg}$ plant $^{-1}$, while $41.9 \%$ and $25.6 \%$ of respondents who grew cultivar "Babu kubwa" and "Ismailia" harvested >0 to $1 \mathrm{~kg}$ plant $^{-1}$ during the previous season (2017). The mean yield was $2.6 \mathrm{~kg} \mathrm{plant}^{-1}$. Cultivar "Babu ndogo" had a significantly $\left(\chi^{2}=13.5, d f=5, p=0.019\right)$ higher yield compared to the other cultivars.

Based on focus group discussions, the cultivars were first introduced from other areas and farmers subsequently named them locally using Swahili and the native Luguru language, based on aspects including characteristic morphological features and source of the planting materials. Farmers also reported securing planting materials/cuttings of these cultivars from their neighbours, 

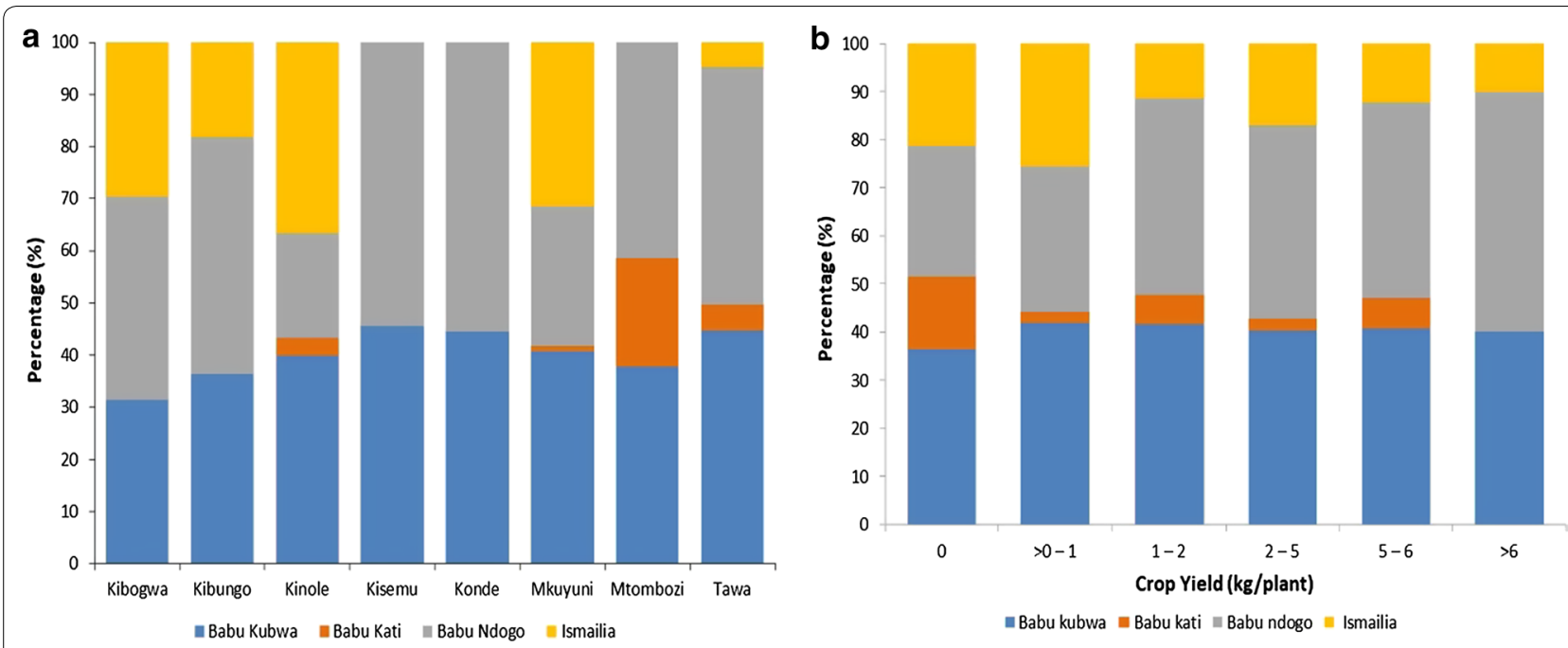

Fig. 4 Results of a survey of villages in Morogoro district, Tanzania, where pepper farms were surveyed for symptoms of spike shedding and stem wilting. a Preference of pepper cultivars by wards surveyed. $\mathbf{b}$ Productivity of pepper cultivars grown in Morogoro district

with their choices guided by the preference for particular morphological features and availability of cuttings.

Based on field observation, "Babu kubwa" had larger leaves and longer spikes compare to the other cultivars. "Babu kati" possessed long-narrow leaves and spikes when compared to "Ismailia" and "Babu ndogo" which have short-broad leaves, while "Babu ndogo" had the shortest spikes compared to all other cultivars. The distinguishing features of the pepper cultivars based on the size of spikes and leaves are presented (Fig. 5a, b).

\section{Pepper spike shedding and stem wilting}

The majority $(69 \%)$ of respondents reported having observed the spike shedding and stem wilting disorders of pepper on their farms for more than 3 years but not for longer than 7 years, followed by less than 2 years $(25 \%)$ and only $6 \%$ of respondents reported not to have observed the disorders in pepper plants on their farms. The difference in proportions of affected pepper cultivars across the different wards surveyed was significant for cultivars "Babu kubwa" ( $\left.\chi^{2}=20.75, d f=7, p=0.004\right)$, "Babu ndogo" $\left(x^{2}=25.22, d f=7, p=0.001\right)$, "Babu kati" $\left(\chi^{2}=39.78, d f=7\right.$, $p<0.001)$ and "Ismailia" $\left(x^{2}=89.35, d f=7, p<0.001\right)$. Most (19.2\%) farmers in Mtombozi ward reported incidence of shedding and stem wilting on pepper cultivar "Babu kati." The majority (28.9\%) of farmers in Mkuyuni and Kibogwa wards reported cultivar "Ismailia" as the most affected, while a larger proportion of farmers in Kibungo ward reported cultivar "Babu ndogo" (85.7\%), and in Konde ward cultivar "Babu kubwa" (53.8\%), as the most affected (Fig. 5c). With the exception of cultivar "Ismailia" $\left(x^{2}=9.39, d f=7, p<0.002\right)$, the difference in proportions of the cultivars affected specifically by spike shedding across the different wards surveyed was not significant for cultivars "Babu kubwa" $\left(\chi^{2}=0.81, d f=7, p<0.3\right)$, "Babu kati" $\left(x^{2}=0.4, d f=7, p<0.5\right)$ or "Babu ndogo" $\left(\chi^{2}=3.02, d f=7\right.$, $p<0.08)$. The difference in proportions of cultivars specifically affected by stem wilting across the different wards surveyed was not significant for cultivars "Babu kubwa" $\left(\chi^{2}=0.56, d f=7, p=0.5\right)$, "Babu ndogo" $\left(\chi^{2}=0.12, d f=7\right.$, $p=0.7)$ and "Ismailia" $\left.\chi^{2}=2.07, d f=7, p=0.2\right)$, but was for cultivar "Babu kati" ( $\left.\chi^{2}=8.38, d f=7, p=0.004\right)$.

The pepper production constraints (flower shedding, spike shedding and stem wilting) reported by the interviewees are summarized (Fig. 6a). Based on Fisher's Exact Test, results indicate a significant difference $(p<0.001)$ in the occurrence of these pepper production constraints with altitude. Spike shedding was more prominent among $85.7 \%$ of respondents at 300 masl and 380 masl (61.1\%), whereas stem wilting was reported by the majority (66.7\%) of respondents at 457 masl and 452 masl (55.6\%). On the other hand, flower shedding was reported by most farmers at 321 masl (43.9\%), 660 masl (48\%), and 806 masl (41.5\%). However, despite these numeric differences the regression analysis (Fig. 6b) did not show a significant relationship between altitude and the incidence of stem wilting $\left(r=-0.372, R^{2}=0.138, p=0.2\right)$, or incidence of spike shed$\operatorname{ding}\left(\mathrm{r}=-0.142, \mathrm{R}^{2}=0.02, p=0.6\right)$.

\section{Seasonal occurrence, management practices and characteristics of pepper spike shedding and stem wilting}

Following the survey, seasonal occurrence, management practices, and characteristics of pepper spike 

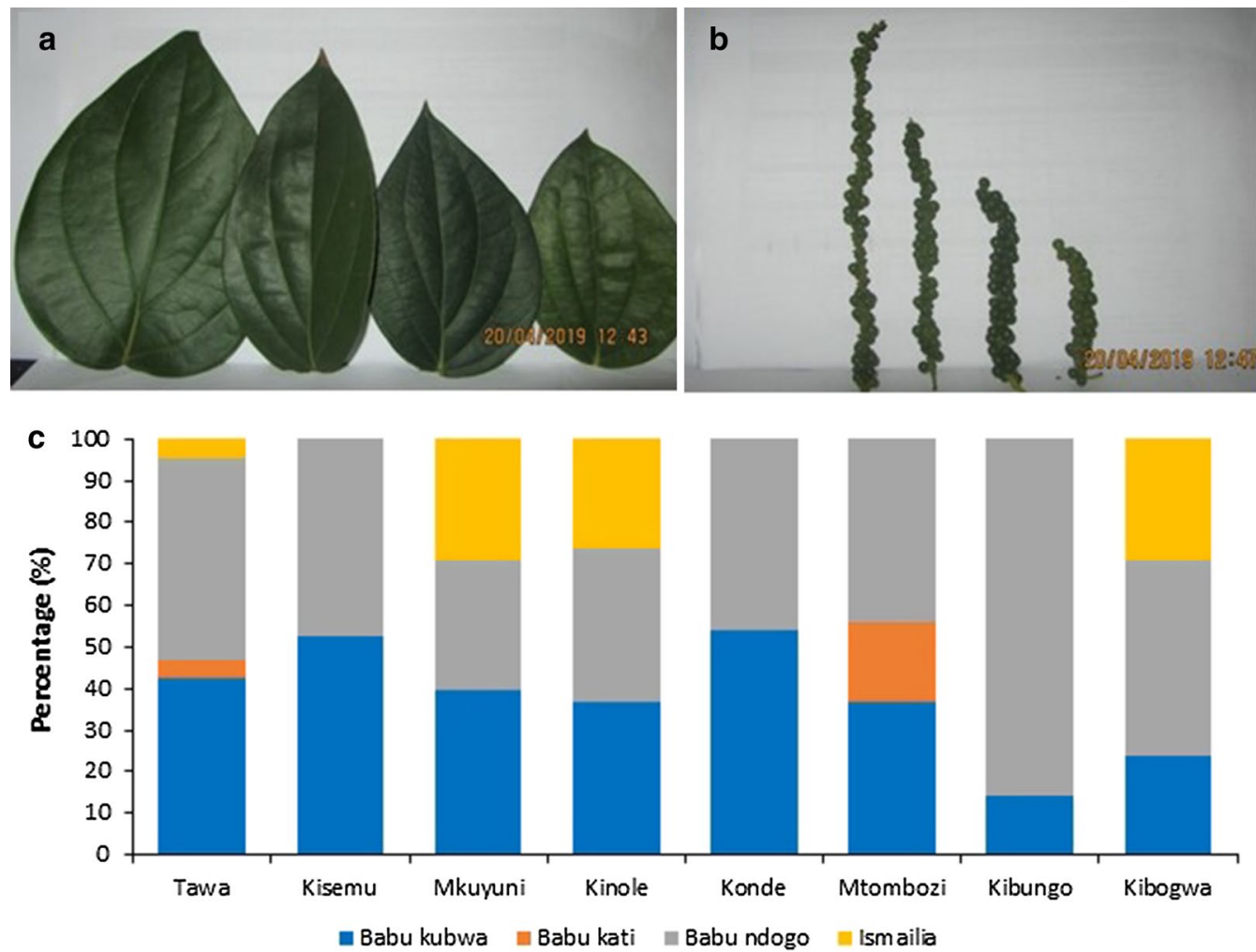

Fig. 5 Results of a survey of villages in Morogoro district, Tanzania, where pepper farms were surveyed for symptoms of spike shedding and stem wilting. The pepper cultivars were distinguished based on the size of spikes and leaves. From left in the photos represents $\mathbf{a}$ Leaves and $\mathbf{b}$ spikes of pepper cultivar Babu kubwa, Babu kati, Ismailia, and Babu ndogo. c Responses of interviewed farmers on the most affected pepper cultivars based on their observations

shedding and stem wilting were summarized (Table 4). Approximately $93 \%$ of interviewed farmers reported that high incidences of pepper spike shedding and stem wilting occured during the dry season. About $79 \%$ and $55 \%$ reported fruit setting and flowering as the most affected growth stages. The proportions of different pepper vine support species in the different wards did not differ significantly with incidence of spike shedding across the different wards surveyed (Jatropha $\left(\chi^{2}=0.09\right.$, $d f=7, p=0.8)$, Mango $\left(x^{2}=0.21, d f=7, p=0.6\right)$, Kapok $\left(\chi^{2}=2.91, d f=7, p=0.9\right)$, Jackfruit $\left(\chi^{2}=0.68, d f=7\right.$, $p=0.4)$ ). The difference between proportions of different pepper vine support species and stem wilting incidence across the different wards surveyed was not significant (Jatropha $\left(\chi^{2}=2.09, d f=7, p=0.2\right)$, Mango $\left(\chi^{2}=2.98\right.$, $d f=7, p=0.09)$, Kapok $\left(\chi^{2}=0.11, d f=7, p=0.7\right)$, Jackfruit $\left.\left(\chi^{2}=0.11, d f=7, p=0.7\right)\right)$. Nevertheless, the majority $(52.8 \%)$ of respondents reported pepper plants suffered from these disorders where Jatropha was used as the supporting materials for training their pepper plants. A greater proportion (92.1\%) of interviewed farmers reported applying no measures for controlling spike shedding and stem wilting. Only $8 \%$ of the interviewed farmers reported uprooting wilting pepper plants for replanting, removing wilting stems, and application of botanical pesticides (Chili, Ginger, Garlic and Neem plant extracts) for controlling the disorders. About $72 \%$ of respondents reported characterizing the disorders by leaf yellowing, while $21.3 \%$ of farmers associated spike shedding and stem wilting with some insects observed on the pepper plants, and $25.9 \%$ of farmers observed drying of leaves and defoliation. The appearance of the wilting plants is shown (Fig. 7).

\section{Discussion}

The results show that individual farmers have engaged in pepper production from 1 to 15 years or more. Those farmers who have grown pepper for more years are presumably more experienced. However, pepper production in Morogoro district in Tanzania is dominated by poor adoption of key agronomic practices including soil management, irrigation and fertilizer application (and many other practices). Maerere and Van Noort (2014) reported that the traditional production systems in various pepper producing areas in Tanzania including Morogoro district have not improved over time despite the extensive (many 

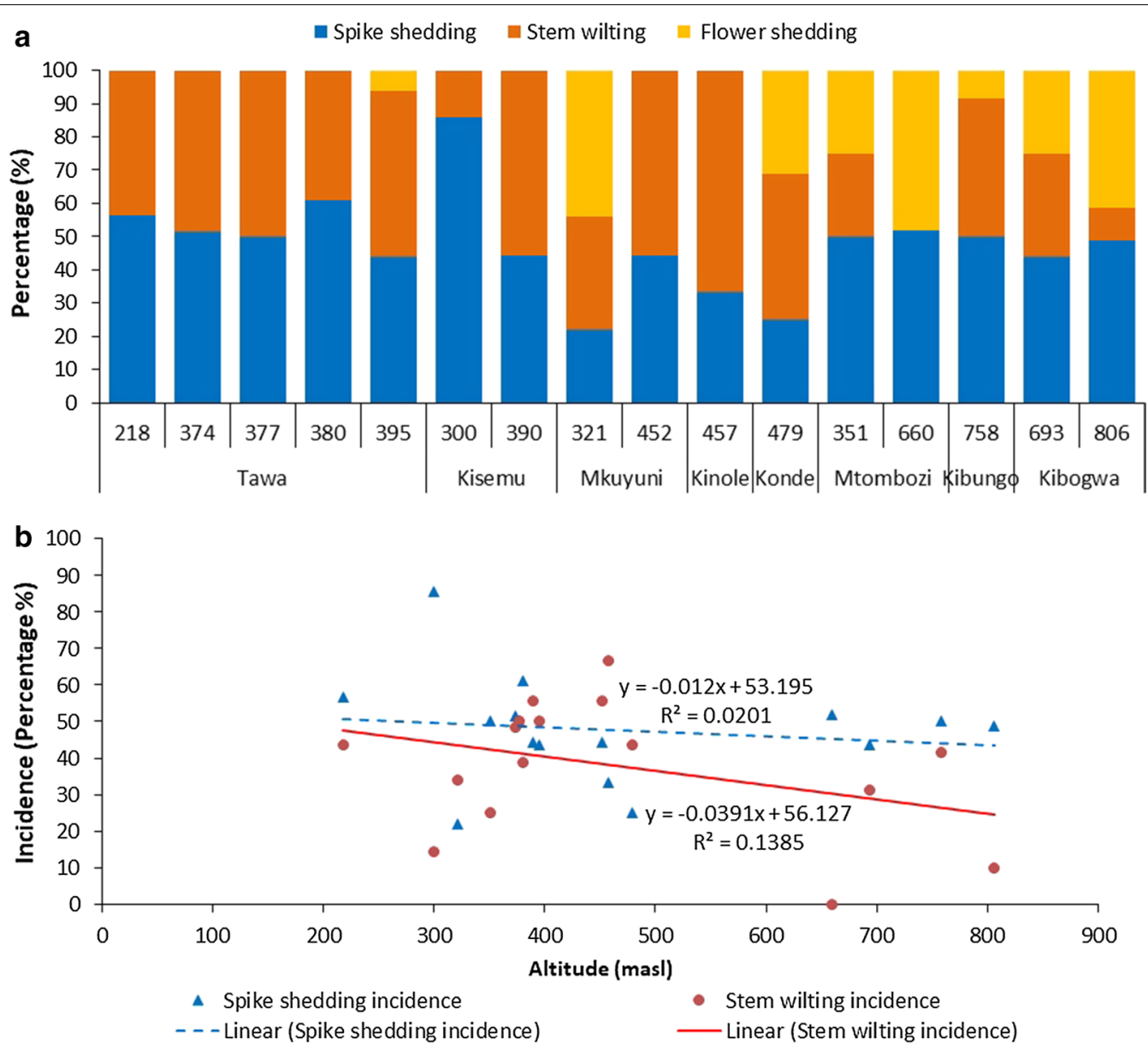

Fig. 6 Results of a survey of villages in Morogoro district, Tanzania, where pepper farms were surveyed for symptoms of spike shedding and stem wilting. a Responses of interviewed farmers on the pepper production constraints in Morogoro district. $\mathbf{b}$ Regression analysis between altitude and the incidence of spike shedding and stem wilting

years) growing experience of some farmers, and is most likely due to the lack of a specialized extension service.

The high incidence of spike shedding and stem wilting reported in low-altitude areas might be linked to the relatively high temperature and the poorer drainage that may be associated with lower altitudes compared to high altitude areas. Msanya et al. (2001) reported that soils at low altitudes in Morogoro district are massive and structureless with imperfect to poor drainage. However, soils at high altitudes have weak to sub-angular blocky structures, are soft to slightly hard when dry, friable when moist, slightly sticky to sticky when wet with moderate to excessive drainage. Ploetz (2007) reported that diseases affecting perennial crops in the tropics can be significant constraints to production especially when they occur in low land environments with relatively high and uniform rainfall and warm temperature.

Variation in the seasonal occurrence of spike shedding and stem wilting reported in the study area in Morogoro district might be associated with either an increase in pathogens and/or prevailing weather condition which exacerbate the condition. Previous studies by Krishnamurthy et al. (2016) and Srinivasan et al. (2012) have indicated that dry conditions during the critical period between flowering and fruit development contribute to the occurrence of spike shedding of pepper in India. In apparent contradiction, a rapid fall in light intensity and photosynthetic rate as a result of the heavy rains and cloudy weather was associated with increased spike shedding from $1.7 \%$ in May to $51.3 \%$ in June for the pepper variety Panniyur-1 grown at high altitudes in areas of India (Ravindran et al. 2000). Furthermore, Thomas and Naik (2017) reported a low incidence (5\%) of wilting pepper plants due to an oomycete, $P$. capsici in villages at high altitudes in India during the short-rain period compared to during hot and dry periods (50 to 65\% incidence). Thus, neither the biotic or abiotic causes of spike shedding and stem wilting are clearly defined or 
Table 4 Seasonal occurrence, management practices and characteristics of pepper spike shedding and stem wilting on pepper farms in Morogoro district, Tanzania

\begin{tabular}{|c|c|c|}
\hline Variable & Criteria for difference & $\begin{array}{l}\text { Frequency (percentage) }{ }^{1} \\
\text { of respondents } n=216\end{array}$ \\
\hline \multirow[t]{2}{*}{ Season of the year with high severity } & Dry (June-October) & $201(93.1)^{\mathrm{a}}$ \\
\hline & Rainy (February-May) & $76(35.2)$ \\
\hline \multirow[t]{4}{*}{ Pepper growth stages more prone } & Vegetative & $85(39.4)$ \\
\hline & Flowering & $119(55.1)$ \\
\hline & Fruiting & $127(78.8)$ \\
\hline & Fruit maturity & $95(44.0)$ \\
\hline \multirow[t]{5}{*}{ Support materials with affected pepper plants } & Jatropha & $114(52.8)$ \\
\hline & Kapok & $107(49.5)$ \\
\hline & Jackfruit & $96(44.5)$ \\
\hline & Mango & $51(23.6)$ \\
\hline & Others & $48(22.2)$ \\
\hline \multirow[t]{3}{*}{ Features observed on pepper plants } & Leaf yellowing & $155(71.8)$ \\
\hline & Drying of leaves and defoliation & $56(25.9)$ \\
\hline & Insect pests & $46(21.3)$ \\
\hline \multirow[t]{4}{*}{ Practices applied as measures to alleviate the disorders } & Uproot and replant & $11(5.1)$ \\
\hline & Cut-off affected stems & $4(1.9)$ \\
\hline & Applied Botanicals & $2(0.9)$ \\
\hline & None & $199(92.1)$ \\
\hline
\end{tabular}

a Numbers in parenthesis indicate the percentage of respondents at specified category; where \% totals add up to more than $100 \%$ there were multiple categories selected by responders

understood. It may also be that spike shedding and stem wilting are a stress-response related to a range of different causes.

In Morogoro district, the high incidences of spike shedding and stem wilting reported by farmers whose pepper plants were trained on Jatropha was possibly due to susceptibility to pathogens including Fusarium spp (F. solani). Zarafi and Abdulkadir $(2012,2013)$ found that Fusarium spp (F. solani) caused wilting of Jatropha, and when inoculated to determine host range, the fungus induced typical wilting symptoms on other crops including sesame, groundnut, and soya beans. Fusarium spp (including F. solani and F. oxysporum) have been reported to cause stem wilting of pepper plants in Brazil and Malaysia (Duarte et al. 1999, 2001; Shahnazi et al. 2012). These studies reported symptoms including yellowing of foliage, drying and defoliation of pepper plants similar to those symptoms observed in Morogoro district. Plant wilting caused by fungi such as Fusarium spp. are generally severe when a susceptible host is planted and the pathogen inoculum can build-up quickly due to favourable environmental conditions (Agrios 2005).

Historically, spike shedding and stem wilting in Morogoro district has only been observed in the relatively recent past (based on our results, during the last 7 years). The high incidence may be attributed to the expansion of pepper production, sourcing of possibly diseased or poor planting material from neighbours, the introduction of new cultivars from other pepper-producing areas; such cultivars include "Ismailia", "Babu kubwa" and "Babu ndogo" which were reported by the pepper farmers to be more affected by spike shedding and stem wilting, the poor adoption of key agronomic practices including soil management (particularly irrigation and fertilization) and lack of knowledge of control measures for spike shedding and stem wilting, whether it is ascertained to be caused by a plant pathogen or by other non-pathogen related plant husbandry practices. Similar findings have also been reported for wilt diseases of banana (Muchuruza and Melchior 2013; Ramadhani et al. 2017) and rice (Hashim et al. 2018). Yield loss, and therefore profit for pepper farmers in Morogoro district is being adversely affected by the extent of spike shedding and stem wilting. Based on these observations it seems compelling that the etiology of the condition be elucidated. Only then can measures for management be tested and eventually recommended.

\section{Conclusions}

Spike shedding and stem wilting occurred to a greater extent at low altitude compared to high altitude areas in Morogoro district in Tanzania. The degree of spike shedding and stem wilting differed among the pepper cultivars grown regardless of the type of support plants used. 

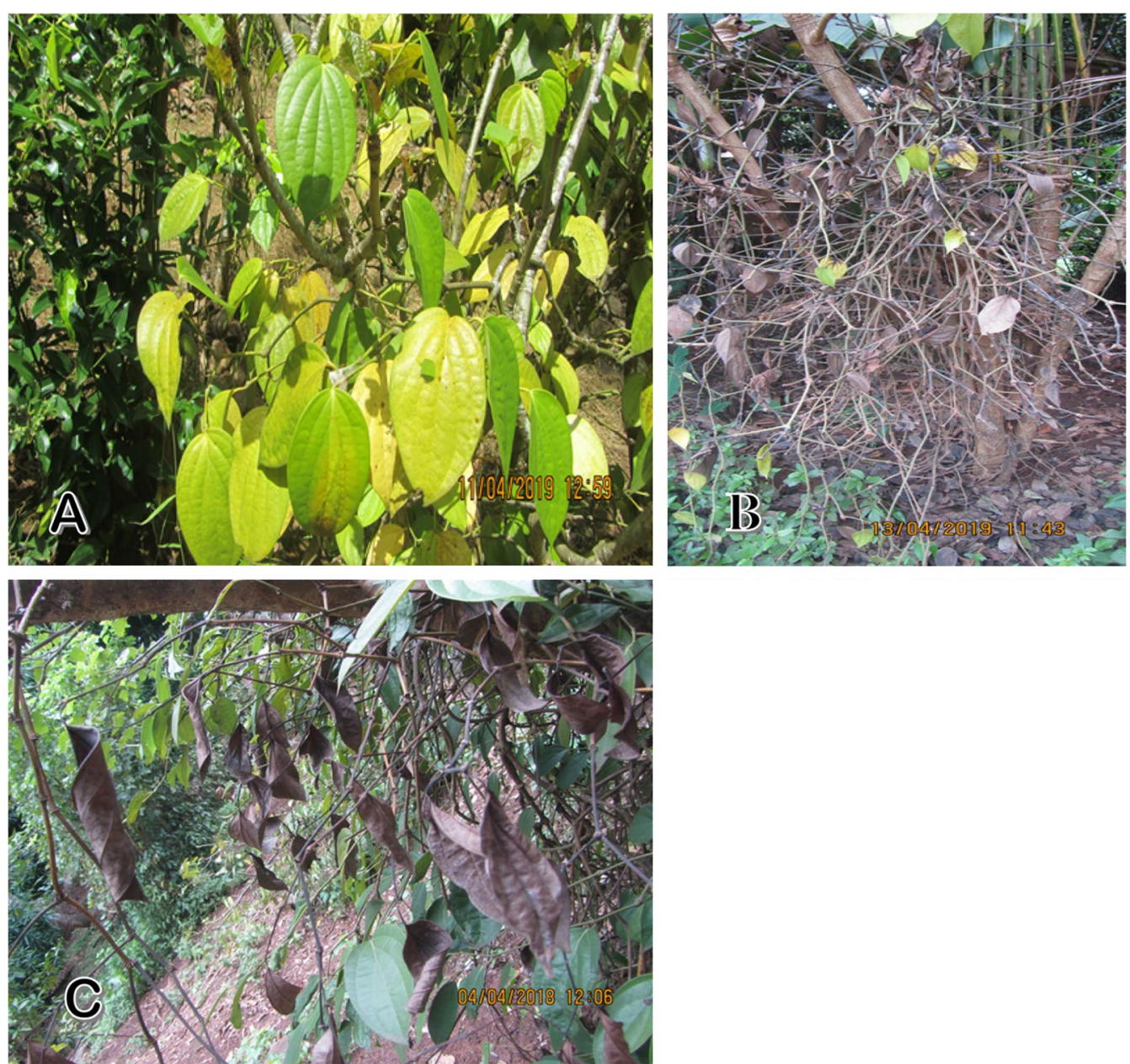

Fig. 7 Appearance of wilting pepper plants observed in the study area. a Leaf yellowing; $\mathbf{b}$ defoliation; and $\mathbf{c}$ Leaves drying on pepper plants

Drought conditions, cultural practices including usage of support plants known to be susceptible to pathogens, poor adoption of key agronomic practices including irrigation and fertilizer application were possibly factors associated with the prevalence and spread of spike shedding and stem wilting. The introduction of cultivars from other pepper-producing areas and the exchange of planting materials among farmers, suggests the possible dissemination of disease-causing agents, but confirmation is needed. Lack of knowledge of the etiology of spike shedding and stem wilting prevents adopting control measures which could reduce the magnitude of problem. Our study has provided a baseline defining the current status of spike shedding and stem wilting in Morogoro district in Tanzania. This information can be used to initiate a process to identify the abiotic and/or biotic causal agent(s) of spike shedding and stem wilting, which will in turn be the basis for developing appropriate management measures.

\section{Supplementary information}

Supplementary information accompanies this paper at https://doi. org/10.1186/s43170-020-00006-7.

Additional file 1. Questionnaire used for data collection among pepper growers in Morogoro District, Tanzania.

\section{Abbreviations}

a.i: Active ingredient; masl: Meters above sea level; NAA: 1-Naphthaleneacetic acid.

\section{Acknowledgements}

The authors are also grateful to pepper farmers in Mkuyuni and Matombo divisions of the Morogoro district who facilitated this work in many ways to completion.

\section{Authors' contributions}

AS performed the conception or design of the work, data collection, data analysis, interpretation, and was a major contributor in writing the manuscript (drafting the article). RM and AM performed a critical revision of the article, providing critical comments concerning the discussion of results, conclusions, and recommendations. All authors read and approved the final manuscript. 


\section{Funding}

The authors frankly thank the Sustainable Agriculture Tanzania (SAT) through the workshop for participatory research design (WPRD) for providing financial support to undertake this study.

\section{Availability of data and materials}

The datasets used and/or analysed during the current study are available from the corresponding author on reasonable request.

\section{Ethics approval and consent to participate}

Not applicable.

\section{Consent for publication}

Not applicable.

\section{Competing interests}

The authors declare that they have no competing interests.

Received: 4 December 2019 Accepted: 17 June 2020

Published online: 25 June 2020

\section{References}

Agrios GN. Plant pathology. USA: Elsevier Academic Press; 2005. p. 922. Bhai RS, Eapen SJ, Kumar A, Aravind R, Pervez R, Varghese EM, Sreeja K. Mitigating Phytophthora foot rot and slow decline diseases of black pepper through the deployment of bacterial antagonists. J Spi Aro Crps. 2017;26:69-82.

Burgess ND, Karamaga O, Ludovic RA, Matembo Y, Hymas O. Explanatory notes on the creation of the Uluguru Mountains Biodiversity Conservation Project Geographical Information System. Dar es Salaam: Wildlife Conservation Society; 2001.

Daba T, Kifelew H, Hailemichael G, Getachew W. Insect pests infesting black pepper (Piper nigrum L.) in southwestern part of Ethiopia. Afr JAgr Res. 2017;12:1817-23.

Duarte MLR, Albuquerque FC, Hamada M, Costa AP. Murcha causada por Fusarium oxysporum, uma nova doença da pimentado-reino no Estado do Pará (Black pepper wilt-caused by Fusarium oxysporum in the state of Para). Fit Bra J. 1999;24:78-181.

Duarte M, de Albuquerque FC, Chu EY. New diseases affecting black pepper crop in Brazil. In: Embrapa Amazônia Oriental-Artigo em anais de congresso (ALICE) 2001. International Pepper News Bulletin, Brazil; 2001

Geetha CK, Nair PC. Studies on spike shedding in black pepper (Piper nigrum L.) Cv. Panniyur I. South Indian Hort. 1989;37:282-86.

Hamza S, Sadanandan AK. Effects of sources and method of zinc application on yield and quality of black pepper (Piper nigrum L). J Spi Aro Crps. 2005:14:117-21.

Hashim I, Mamiro DP, Mabagala RB, Tefera T. Smallholder farmers'knowledge, perception and management of rice blast disease in upland rice production in Tanzania. J Agr Sci. 2018;10:137-45.

Kandiannan K, Sivaraman K, Thankamani CK. Growth regulators in black pepper production. Ind Coc Arec Spices J. 1994;18:119-23.

Krishnamoorthy B, Parthasarathy VA. Improvement of black pepper. Per Agr Sci Nut Nat Res. 2009:4:12.

Krishnamurthy KS, Ankegowda SJ, Umadevi P, George JK. Black pepper and water stress: abiotic stress physiology of horticultural crops. In: Rao N, Shivashankara K, Laxman R, editors. India: Springer; 2016. p. 321-2.

Kumar AR, Sathiamoorthy S, Subbiah A. Effect of plant growth regulators on yield parameters, yield and quality of black pepper (Piper nigrum L.) variety Panniyur-1. J Spi Aro Crps. 2002;11:125-8.

Maerere AP, Van Noort WCJ. Tanzania spices sub sector strategy technical report. Geneva: International Trade Centre; 2014

Menon R, Nair PC. Studies on spike shedding in black pepper var panniyur-1. South Indian Hort. 1987;35:438-41.

Meteoblue Climate Modelled: Kinole Tanzania. University of Basel, Switzerland; 2018. https://www.meteoblue.com. Accessed 7 Nov 2018.

Msanya BM, Kimaro DN, Kileo EP, Kimbi GG, Munisi Al. Land resources inventory and suitability assessment for the production of the major crops in the eastern part of Morogoro Rural District, Tanzania. In: Soils and land resources of Morogoro rural and urban districts Vol 3. Department of Soil Science, Sokoine University of Agriculture; 2001.

Muchuruza YP, Melchior HR. The effects of Banana Xanthomonas Wilt (BXW) on food security and the people's livelihood: the case of Nshamba and Rubale divisions in Kagera Region. Tanzania: Kagera Development Trust Fund and Centre for Development Initiatives; 2013.

Nguyen LN. Spread of Phytophthora capsici in black pepper (Piper nigrum) in Vietnam. Engineering. 2015;7:506-13.

Parthasarathy VA, Zachariah TJ. Black pepper: chemistry of spices In: Parthasarathy VA, Chempakam B, Zachariah TJ, editors. London: Biddles Ltd; 2008. p. 21-40.

Parthasarathy VA, Sasikumar B, Nair RR, George JK. Black pepper: botany and horticulture. In: Janick J, editor. Horticultural Reviews. India: Indian Council of Agricultural Research; 2007. p. 173-266.

Ploetz RC. Diseases of tropical perennial crops: challenging problems in diverse environments. J Plant Dis. 2007;91:644-63.

Purseglove JW, Brown EG, Green CC, Robbins SRJ. Spices, vol. 1. Longman: Scientific and Technical; 1981.

Ramadhani K, Machuve D, Jomanga K. Identification and Analysis of Factors in Management of Banana Fungal Diseases: case of Sigatoka (MycosphaereIla fijiensis. Mulder and Fusarium (Fusarium Oxysporum f. sp. cubense (foc) Diseases in Arumeru District. J Bio Env Sci. 2017;11:69-75.

Ravindra H, Sehgal M, Manu TG, Murali R, Latha M, Narasimhamurthy HB. Incidence of root-knot nematode (Meloidogyne incognita) in black pepper in Karnataka. J Ent Nem. 2014;6:51-5.

Ravindran PN, Babu KN, Sasikumar B, Krishnamurthy KS. Botany and crop improvement: Black pepper (Pipernigrum). In: Ravindran PN, editor. Amsterdam: Harwood Academic publishers; 2000. p. 23-142.

Shahnazi S, Meon S, Vadamalai G, Ahmad K, Nejat N. Morphological and molecular characterization of Fusarium spp. associated with yellowing disease of black pepper (Piper nigrum L.) in Malaysia. J Gen Plant Path. 2012;78:160-9.

Srinivasan V, Dinesh R, Krishnamurthy KS, Hamza S. Nutrition and physiology: piperaceae crops - production and utilization. In: Singh HP, Parthasarathy VA, Srinivasan V, editors. India: Westville Publishing House; 2012. p. $101-21$.

Thangaselvabal T, Gailce LJC, Leelamathi M. Black pepper (Piper nigrum L.)'the king of spices'-A review. Agric Rev. 2008;29:89-98.

Thomas LM, Naik BG. Survey for the Incidence of Foot Rot of Black Pepper Caused by Phytophthora capsici Leonian in Shivamogga and Chickmagaluru Districts of Karnataka State. Int J Pure Appl Bio Sci. 2017:5:293-8.

Tran TPH, Wang SL, Nguyen VB, Tran DM, Nguyen DS, Nguyen AD. Study of novel endophytic bacteria for biocontrol of black pepper root-knot nematodes in the central highlands of Vietnam. J Agr. 2019;9:1-13.

Truong NV, Burgess LW, Liew ECY (2005) Survey of quick wilt of black pepper in Vietnam. In: The 15th biennial Australasian Plant Pathology Society conference handbook. Australasian Plant Pathology Society.

Truong NV, Burgess LW, Liew ECY. Greenhouse and field evaluations of potassium phosphonate: the control of Phytophthora foot rot of black pepper in Vietnam. Arch Phytopathol Plant Prot. 2012:45:724-39.

Yamane Y, Kularatne J, Ito K. International diversity of cropping patterns and factors affecting home garden cultivation in Kibogwa on the Eastern Slopes of the Uluguru Mountains in Tanzania. J Agric. 2018;8:20.

Zarafi AB, Abdulkadir ID. Identification and host range of causal agent of dieback disease on Jatropha curcas. Arch Phytopathol Plant Prot. 2012:45:1096-100.

Zarafi AB, Abdulkadir ID. The incidence and severity of Jatropha dieback disease in Zaria, Nigeria. Arch Phytopathol Plant Prot. 2013;46:952-61.

Zaragoza BA, Castillo MB, Dag LL. Etiology of the Yellowing and Wilt Disease of Black Pepper (Piper nigrum L.) including Biocontrol. Trans Nat Acad Sci Tech. 1992;14:513-29.

\section{Publisher's Note}

Springer Nature remains neutral with regard to jurisdictional claims in published maps and institutional affiliations. 